\begin{tabular}{|c|c|}
\hline Title & AnXAFS study on the specific microstructure of active species in iron titanate catalyst for NH3-SCR of NOX \\
\hline Author(s) & Liu, Fudong; A sakura, Kiyotaka; X ie, Pengy ang; W ang, Jianguo; He, Hong \\
\hline Citation & $\begin{array}{l}\text { Catalysis Today, 201, 131-138 } \\
\text { https://doi.org/10.1016/.cattod.2012.03.062 }\end{array}$ \\
\hline Issue Date & 2013-03-01 \\
\hline DOC URL & http:/hdl.handle.net/2115/52113 \\
\hline Type & article (author version) \\
\hline File Information & СT201_131-138.pdf \\
\hline
\end{tabular}

Instructions for use 


\section{An XAFS study on the specific microstructure of active species in iron titanate catalyst for $\mathrm{NH}_{3}-\mathrm{SCR}$ of $\mathrm{NO}_{x}$}

Fudong Liu ${ }^{\mathrm{a}}$, Kiyotaka Asakura*b ${ }^{\mathrm{b}}$, Pengyang Xie ${ }^{\mathrm{c}}$, Jianguo Wang $^{\mathrm{c}}, \mathrm{Hong}^{\mathrm{H}} \mathrm{He}^{*^{\mathrm{a}}}$

${ }^{a}$ State Key Laboratory of Environmental Chemistry and Ecotoxicology, Research

Center for Eco-Environmental Sciences, Chinese Academy of Sciences, Beijing 100085, P.R. China

${ }^{\mathrm{b}}$ Catalysis Research Center, Hokkaido University, Sapporo 001-0021, Japan.

${ }^{\mathrm{c} C o l l e g e}$ of Chemical Engineering and Materials Science, Zhejiang University of Technology, Hangzhou 310032, P.R. China.

* Corresponding author.

Tel: 86-10-62849123; Fax: 86-10-62849123;

E-mail: honghe@rcees.ac.cn (H. He)

Postal address: P.O. Box 2871, 18 Shuangqing Road, Haidian District, Beijing 100085,

P.R. China

${ }^{* \mathrm{~b}}$ Corresponding author.

Tel: 81-11-706-9113; Fax: 81-11-706-9113;

E-mail: askr@ cat.hokudai.ac.jp (K. Asakura)

Postal address: Catalysis Research Center, Hokkaido University, 21-10 Kita, Sapporo 001-0021, Japan 


\section{Abstract}

Environmental-friendly iron titanate $\left(\mathrm{FeTiO}_{x}\right)$ catalyst is a potential candidate for the substitution of conventional $\mathrm{V}_{2} \mathrm{O}_{5}-\mathrm{WO}_{3}\left(\mathrm{MoO}_{3}\right) / \mathrm{TiO}_{2}$ catalyst for the selective catalytic reduction of $\mathrm{NO}_{x}$ with $\mathrm{NH}_{3}\left(\mathrm{NH}_{3}-\mathrm{SCR}\right)$ for the $\mathrm{NO}_{x}$ elimination from stationary and mobile sources for environmental protection. To understand in-depth the nature of active structure in this $\mathrm{FeTiO}_{x}$ catalyst for further catalyst redesign and activity improvement, the study of X-ray absorption near-edge spectroscopy (XANES) and extended X-ray absorption fine-structure spectroscopy (EXAFS) combined with theoretical calculation is carefully performed. Different from the crystal structure of hematite $\mathrm{Fe}_{2} \mathrm{O}_{3}$, homogeneous edge shared $\mathrm{Fe}^{3+}-(\mathrm{O})_{2}-\mathrm{Ti}^{4+}$ structure in $\mathrm{FeTiO}_{x}$ catalyst prepared from $\mathrm{Ti}\left(\mathrm{SO}_{4}\right)_{2}$ precursor is obviously formed with crystallite phase, which shows the electronic inductive effect between $\mathrm{Fe}^{3+}$ and $\mathrm{Ti}^{4+}$ species, resulting in the high NO adsorption and oxidation ability of $\mathrm{Fe}^{3+}$ species and thus high catalytic activity and $\mathrm{N}_{2}$ selectivity in the $\mathrm{NH}_{3}$-SCR reaction. In the future study, this specific edge shared $\mathrm{Fe}^{3+}-(\mathrm{O})_{2}-\mathrm{Ti}^{4+}$ structure can be stabilized onto certain catalyst supports with large surface area for practical use, such as the catalytic removal of $\mathrm{NO}_{x}$ from flue gas and diesel engine exhaust.

Keywords: Iron titanate catalyst; Selective catalytic reduction; Environmental-friendly; XANES; EXAFS; Electronic inductive effect. 


\section{Introduction}

Selective catalytic reduction of $\mathrm{NO}_{x}$ with $\mathrm{NH}_{3}\left(\mathrm{NH}_{3}-\mathrm{SCR}\right)$ is a well-proven technique for the removal of $\mathrm{NO}_{x}$ from stationary and mobile sources for environmental protection, such as coal-fired power plants and diesel engines [1]. Due to some inevitable disadvantages of the conventional and commercial SCR catalyst $\mathrm{V}_{2} \mathrm{O}_{5}-\mathrm{WO}_{3}\left(\mathrm{MoO}_{3}\right) / \mathrm{TiO}_{2}$ including the narrow operation temperature window, the low $\mathrm{N}_{2}$ selectivity at high temperatures due to the formation of large amount of $\mathrm{N}_{2} \mathrm{O}$, the high conversion of $\mathrm{SO}_{2}$ to $\mathrm{SO}_{3}$ and the toxicity of vanadium pentoxide to eco-environment and human health, although it has been applied for several decades in industry, many researchers still make great effort to develop new, highly efficient, stable, environmental-friendly and vanadium-free $\mathrm{NH}_{3}$-SCR catalysts, such as $\mathrm{Fe} / \mathrm{Cu} / \mathrm{Ce}$-exchanged zeolites [2-9] and $\mathrm{Fe} / \mathrm{Cu} / \mathrm{Mn} / \mathrm{Ce}$ supported-type or mixed oxide catalysts [10-21]. Several vanadium-free catalysts have already been utilized for the catalytic removal of $\mathrm{NO}_{x}$ from diesel engine exhaust in recent years, such as Fe/Cu-ZSM-5 catalysts [22].

In our previous study, we have successfully developed a novel and environmental-friendly iron titanate $\left(\mathrm{FeTiO}_{x}\right)$ catalyst prepared by conventional co-precipitation method, which showed high $\mathrm{NH}_{3}-\mathrm{SCR}$ activity, $\mathrm{N}_{2}$ selectivity and $\mathrm{H}_{2} \mathrm{O} / \mathrm{SO}_{2}$ durability in the medium temperature range $\left(200-400{ }^{\circ} \mathrm{C}\right)[23-26]$. This $\mathrm{FeTiO}_{x}$ catalyst is promising to be used in the deNO $\mathrm{N}_{x}$ process for flue gas and diesel engine exhaust for environmental protection. We deduced that the iron titanate crystallite with specific Fe-O-Ti structure, but not aggregated $\mathrm{Fe}_{2} \mathrm{O}_{3}$ oxide particles, 
was the real active phase in the $\mathrm{NH}_{3}$-SCR reaction. However, no direct evidence was obtained from X-ray diffraction (XRD), UV-vis diffuse reflectance spectroscopy (UV-vis DRS), transmission electron microscopy (TEM) and Raman spectroscopy etc. due to the poor crystallinity of this catalyst both in the bulk phase and on the surface. In order to understand in-depth the structural nature of the active phase in this $\mathrm{FeTiO}_{x}$ catalyst for further catalyst redesign and activity improvement, more powerful characterization method for determining the local structure of catalytic materials should be applied, such as the X-ray absorption fine-structure spectroscopy (XAFS).

In this study, using X-ray absorption near-edge spectroscopy (XANES) and extended X-ray absorption fine-structure spectroscopy (EXAFS), we confirm that a homogeneous linkaged structure of edge shared $\mathrm{Fe}^{3+}$ octahedra and $\mathrm{Ti}^{4+}$ octahedra with severe distortion is indeed formed in $\mathrm{FeTiO}_{x}$ catalyst with crystallite phase. In addition, the electronic inductive effect between $\mathrm{Fe}^{3+}$ and $\mathrm{Ti}^{4+}$ species will also be verified by the experimental results combined with theoretical calculation, which is very important to enhance the NO adsorption and oxidation ability of $\mathrm{Fe}^{3+}$ species and thus the catalytic activity in $\mathrm{NH}_{3}-\mathrm{SCR}$ reaction. This new finding can provide theoretical guidance for the further design and activity improvement of this $\mathrm{NH}_{3}-\mathrm{SCR}$ catalyst, even for other Fe-Ti containing or mixed oxide catalyst systems.

\section{Experimental}

\subsection{Catalyst preparation}

The iron titanate catalysts were facilely synthesized by conventional co-precipitation method using $\mathrm{TiCl}_{4}$ or $\mathrm{Ti}\left(\mathrm{SO}_{4}\right)_{2}$ as $\mathrm{Ti}$ precursor and $\mathrm{Fe}\left(\mathrm{NO}_{3}\right)_{3} \cdot 9 \mathrm{H}_{2} \mathrm{O}$ 
as $\mathrm{Fe}$ precursor with the molar ratio of $\mathrm{Fe}: \mathrm{Ti}=1: 1$. When using $\mathrm{TiCl}_{4}$ as $\mathrm{Ti}$ precursor, it was firstly diluted with ice-cold distilled water in the bath of ice-water mixture avoiding intense hydrolysis to prepare a known concentration of $\mathrm{TiOCl}_{2}$ solution. Because of the slow hydrolysis of $\mathrm{TiCl}_{4}$ at such a low temperature, no $\mathrm{TiO}_{2}$ precipitation occurred during the preparation process of $\mathrm{TiOCl}_{2}$ solution. Then a stoichiometric amount of $\mathrm{Fe}\left(\mathrm{NO}_{3}\right)_{3}$ aqueous solution was added in with subsequent stirring for $1 \mathrm{~h}$ without the formation of any precipitation in this process, either. Afterwards, standard $\mathrm{NH}_{3} \cdot \mathrm{H}_{2} \mathrm{O}(25$ wt. \%) aqueous solution was used as precipitator until the $\mathrm{pH}$ rose to 10 when the $\mathrm{Fe}$ and $\mathrm{Ti}$ ions were completely co-precipitated. Without aging, the precipitate was filtrated and washed by distilled water to remove the unwanted cations and anions from precursors and precipitator, followed by desiccation in oven at $100{ }^{\circ} \mathrm{C}$ for $12 \mathrm{~h}$ and calcination in muffle furnace at $400{ }^{\circ} \mathrm{C}$ for $6 \mathrm{~h}$ in air condition. Catalyst prepared from $\mathrm{TiCl}_{4}$ precursor was denoted as $\mathrm{FeTiO}_{x}-\mathrm{TiCl}_{4}$

When using $\mathrm{Ti}\left(\mathrm{SO}_{4}\right)_{2}$ as $\mathrm{Ti}$ precursor, $\mathrm{TiOSO}_{4}$ solution could be obtained more easily because the hydrolysis of $\mathrm{Ti}\left(\mathrm{SO}_{4}\right)_{2}$ in $\mathrm{H}_{2} \mathrm{O}$ was much slower than that of $\mathrm{TiCl}_{4}$. $\mathrm{Ti}\left(\mathrm{SO}_{4}\right)_{2}$ and $\mathrm{Fe}\left(\mathrm{NO}_{3}\right)_{3} \cdot 9 \mathrm{H}_{2} \mathrm{O}$ were firstly dissolved together with distilled water without the formation of any precipitation, and then the rest procedures were controlled exactly the same as those of $\mathrm{FeTiO}_{x}-\mathrm{TiCl}_{4}$ catalyst. Catalyst prepared from $\mathrm{Ti}\left(\mathrm{SO}_{4}\right)_{2}$ precursor was denoted as $\mathrm{FeTiO}_{x}-\mathrm{Ti}\left(\mathrm{SO}_{4}\right)_{2}$.

We also prepared $\mathrm{Fe}_{2} \mathrm{O}_{3} / \mathrm{TiO}_{2}$ supported type catalyst $(\mathrm{Fe}: \mathrm{Ti}=1: 1$ in molar ratio) using conventional impregnation method for comparison. The anatase $\mathrm{TiO}_{2}$ support in 
$\mathrm{Fe}_{2} \mathrm{O}_{3} / \mathrm{TiO}_{2}$ catalyst was purchased from Shanghai Huijing Co.. Firstly, the calculated amount of $\mathrm{TiO}_{2}$ support was added into an aqueous solution of $\mathrm{Fe}\left(\mathrm{NO}_{3}\right)_{3} \cdot 9 \mathrm{H}_{2} \mathrm{O}$. After impregnation with stirring for $1 \mathrm{~h}$, the excess water was removed in a rotary evaporator at $80{ }^{\circ} \mathrm{C}$. Then the sample was desiccated in oven at $120{ }^{\circ} \mathrm{C}$ for $12 \mathrm{~h}$, followed by calcination in muffle furnace at $400{ }^{\circ} \mathrm{C}$ for $6 \mathrm{~h}$ in air condition.

For the preparation of reference samples, hematite $\mathrm{Fe}_{2} \mathrm{O}_{3}$ and anatase $\mathrm{TiO}_{2}$ were self-prepared by precipitation method using $\mathrm{Fe}\left(\mathrm{NO}_{3}\right)_{3} \cdot 9 \mathrm{H}_{2} \mathrm{O}$ and $\mathrm{Ti}\left(\mathrm{SO}_{4}\right)_{2}$ as precursors, respectively, and using standard $\mathrm{NH}_{3} \cdot \mathrm{H}_{2} \mathrm{O}(25$ wt.\%) aqueous solution as precipitator. The desiccation and calcination procedures were controlled exactly the same as those of $\mathrm{FeTiO}_{x}-\mathrm{TiCl}_{4}$ and $\mathrm{FeTiO}_{x}-\mathrm{Ti}\left(\mathrm{SO}_{4}\right)_{2}$ catalysts.

Finally, all the calcined samples were crushed and sieved above 200 mesh, and then diluted by flour power with appropriate molar ratios and pressed into thin disks for XANES and EXAFS measurements.

\subsection{Activity test}

The steady state $\mathrm{NH}_{3}$-SCR activity over different catalysts was tested in a fixed-bed quartz tube reactor at atmospheric pressure, and the reaction conditions were controlled as follows: $500 \mathrm{ppm} \mathrm{NO}, 500 \mathrm{ppm} \mathrm{NH}_{3}, 5$ vol.\% $\mathrm{O}_{2}, \mathrm{~N}_{2}$ balance; $0.6 \mathrm{ml}$ catalyst, 20-40 mesh; total flow rate of $500 \mathrm{ml} / \mathrm{min}$ and gas hourly space velocity $($ GHSV $)=50000 \mathrm{~h}^{-1}$. The effluent gas was continuously analyzed using an FTIR spectrometer (Nicolet Nexus 670) equipped with a heated, low volume multiple-path gas cell $(2 \mathrm{~m})$.

\subsection{XAFS measurement and data analysis}


The XANES and EXAFS of Fe-K and Ti-K edges were measured in a transmission mode at room temperature on BL-7C beam line, Photon Factory, Institute of Materials Structure Science, High Energy Accelerator Research Organization (IMSS-KEK), Japan. Fe foil, $\mathrm{FeO}$, hematite $\mathrm{Fe}_{2} \mathrm{O}_{3}$, ilmenite $\mathrm{FeTiO}_{3}$, pseudobrookite $\mathrm{Fe}_{2} \mathrm{TiO}_{5}$, Ti foil, anatase $\mathrm{TiO}_{2}$ (self-prepared) and rutile $\mathrm{TiO}_{2}$ were used as reference samples. The storage ring was operated at $2.5 \mathrm{GeV}$ with $300 \mathrm{~mA}$ as an average storage current. The synchrotron radiation beam line was monochromatized with a Si (111) double crystal monochromator, and mirrors were used to eliminate higher harmonics. The incident and transmitted beam intensities were monitored using ionization chambers filled with pure $\mathrm{N}_{2}$.

XAFS data were analyzed using the REX2000 program (Rigaku Co.). XANES spectra were normalized with edge height and then taken the first-order derivatives to compare the variation of absorption edge energies. EXAFS oscillation $\chi(k)$ was extracted using spline smoothing with a Cook-Sayers criterion [27] and weighted by $k^{3}$ in order to compensate for the diminishing amplitude in high $k$ range because of the decay of the photoelectron wave. Thereafter, the filtered $k^{3}$-weighted $\chi(k)$ was Fourier transformed into $\mathrm{R}$ space ( $k$ range: $2.5-15 \AA^{-1}$ for Fe-K EXAFS and $2.5-13 \AA^{-1}$ for Ti-K EXAFS) with a Hanning function window. In the curve fitting step, the possible backscattering amplitude and phase shift were calculated using FEFF8.4 code [28].

\subsection{Density functional theory (DFT) calculation}

The geometry optimization of the three kinds of stoichiometric $\mathrm{TiO}_{2}, \mathrm{Fe}_{2} \mathrm{O}_{3}$ and $\mathrm{Fe}_{2} \mathrm{TiO}_{5}$ crystals were carried out using Dmol3 module $[29,30]$ in Materials Studio 
software package. The generalized gradient approximation (GGA) with PW91 functional was used to describe the exchange-correlation (XC) effects. The double numerical plus polarization (DNP) basis set was used in the expanded electronic wave function.

The Brillouin zone using the Monkhorst-Pack scheme was sampled by $7 \times 7 \times 3,6$ $\times 6 \times 2$ and $3 \times 7 \times 3$ for $\mathrm{TiO}_{2}, \mathrm{Fe}_{2} \mathrm{O}_{3}$ and $\mathrm{Fe}_{2} \mathrm{TiO}_{5}$, respectively. For all calculations, the convergence in energy and force was set to $10^{-5} \mathrm{eV}$ and $2 \times 10^{-3} \mathrm{eV} / \mathrm{A}$. The atomic charges were calculated using the Hirshfeld approach. The electron density difference of the investigated crystal models was also analyzed.

\section{Results and discussion}

\section{1 $\mathrm{NH}_{3}-\mathrm{SCR}$ activity}

The steady-state $\mathrm{NH}_{3}$-SCR activity over $\mathrm{Fe}_{2} \mathrm{O}_{3} / \mathrm{TiO}_{2}, \quad \mathrm{FeTiO}_{x}-\mathrm{TiCl}_{4}$ and $\mathrm{FeTiO}_{x}-\mathrm{Ti}\left(\mathrm{SO}_{4}\right)_{2}$ catalysts is presented in Fig. 1. As we can see, the operation temperature window of $\mathrm{Fe}_{2} \mathrm{O}_{3} / \mathrm{TiO}_{2}$ is quite narrow, and the highest $\mathrm{NO}_{x}$ conversion can not achieve $100 \%$ either. Over $\mathrm{FeTiO}_{x}-\mathrm{TiCl}_{4}$ catalyst, the SCR activity at temperatures below $300{ }^{\circ} \mathrm{C}$ is quite low, although the SCR activity at temperatures above $300{ }^{\circ} \mathrm{C}$ is similar to that over $\mathrm{FeTiO}_{x}-\mathrm{Ti}\left(\mathrm{SO}_{4}\right)_{2}$ catalyst. In a broad temperature range, the $\mathrm{FeTiO}_{x}-\mathrm{Ti}\left(\mathrm{SO}_{4}\right)_{2}$ catalyst exhibits rather high deNO $\mathrm{O}_{x}$ efficiency, with $c a$. $90 \% \mathrm{NO}_{x}$ conversion obtained from 200 to $350{ }^{\circ} \mathrm{C}$. In short summary, the $\mathrm{NH}_{3}-\mathrm{SCR}$ activity over these three catalysts at low temperatures decreases in the following sequence: $\mathrm{FeTiO}_{x}-\mathrm{Ti}\left(\mathrm{SO}_{4}\right)_{2}>>\mathrm{Fe}_{2} \mathrm{O}_{3} / \mathrm{TiO}_{2}>\mathrm{FeTiO}_{x}-\mathrm{TiCl}_{4}$. New highly active species with specific structure should be formed in the most active $\mathrm{FeTiO}_{x}-\mathrm{Ti}\left(\mathrm{SO}_{4}\right)_{2}$ catalyst, 
which will be discussed in detail in the following sections.

\subsection{XANES}

Fig. 2A and Fig. 2B show the Fe-K XANES of reference samples, $\mathrm{Fe}_{2} \mathrm{O}_{3} / \mathrm{TiO}_{2}$, $\mathrm{FeTiO}_{x}-\mathrm{TiCl}_{4}, \quad \mathrm{FeTiO}_{x}-\mathrm{Ti}\left(\mathrm{SO}_{4}\right)_{2}$ catalysts and their corresponding first-order derivatives, respectively. The first-order derivative peak of the absorption coefficient appears at $7122.6 \mathrm{eV}$ for $\mathrm{Fe}^{2+}$ in $\mathrm{FeO}$, while that for $\mathrm{Fe}^{3+}$ in pristine $\mathrm{Fe}_{2} \mathrm{O}_{3}$ appears at $7123.2 \mathrm{eV}$. Interestingly, this peak appears at $7123.4 \mathrm{eV}$ in $\mathrm{Fe}_{2} \mathrm{TiO}_{5}$ reference sample, indicating the higher absorption edge energy than that of $\mathrm{Fe}_{2} \mathrm{O}_{3}$. This may be due to the electronic inductive effect by surrounding $\mathrm{Ti}^{4+}$ ions, in which the deviation of electron cloud occurs from $\mathrm{Fe}^{3+}$ to $\mathrm{Ti}^{4+}$ species.

As for $\mathrm{Fe}_{2} \mathrm{O}_{3} / \mathrm{TiO}_{2}$ catalyst, the clear XANES pattern of $\mathrm{Fe}-\mathrm{K}$ edge is identical with that of hematite and gives the maximum at $7123.2 \mathrm{eV}$ in the first-order derivative, implying that well crystallized $\mathrm{Fe}_{2} \mathrm{O}_{3}$ exists in this catalyst.

$\mathrm{FeTiO}_{x}-\mathrm{Ti}\left(\mathrm{SO}_{4}\right)_{2}$, the most active catalyst, gives the strongest pre-edge peak indicating the severest structure distortion probably from octahedral coordination. A peak top in the first-order derivative appears at $7123.6 \mathrm{eV}$, indicating the presence of $\mathrm{Fe}^{3+}$. The higher energy of this derivative peak than that of $\mathrm{Fe}_{2} \mathrm{O}_{3}$ sample further indicates the presence of $\mathrm{Fe}^{3+}-\mathrm{O}-\mathrm{Ti}^{4+}$ linkage in this catalyst, in which the neighbouring $\mathrm{Ti}^{4+}$ species draws more electrons from $\mathrm{Fe}^{3+}$ species. This is in well accordance with our previous XPS results, in which the $\mathrm{Fe}^{3+}$ species on $\mathrm{FeTiO}_{x}-\mathrm{Ti}\left(\mathrm{SO}_{4}\right)_{2}$ catalyst showed higher binding energy than that on pristine $\mathrm{Fe}_{2} \mathrm{O}_{3}$ sample [24]. The broad feature in the XANES spectrum of $\mathrm{FeTiO}_{x}-\mathrm{Ti}\left(\mathrm{SO}_{4}\right)_{2}$ catalyst 
may be due to the poor crystallinity of iron titanate species with nano size effect, resulting in the less scattering of photoelectrons by neighbouring unsaturated coordination atoms, which is consistent with the rather broad XRD bumps without obvious diffraction peaks [24]. The iron titanate species may be the aggregates of small particles with specific structure, called as iron titanate crystallite. Sulfate species from $\mathrm{Ti}\left(\mathrm{SO}_{4}\right)_{2}$ precursor may inhibit the formation of large crystal particle in its preparation process [31]. In our previous study [32], only $0.2 \% \mathrm{~S}$ content in molar ratio from the residual sulfate species was detected on the surface of $\mathrm{FeTiO}_{x}-\mathrm{Ti}\left(\mathrm{SO}_{4}\right)_{2}$ catalyst, yet this small amount of sulfate did not result in any SCR activity difference at high temperatures comparing with that of $\mathrm{FeTiO}_{x}-\mathrm{TiCl}_{4}$ catalyst (as shown in Fig. 1). As we mentioned above, the electronic field of $\mathrm{Ti}^{4+}$ species around $\mathrm{Fe}^{3+}$ species will reduce the electron density of $\mathrm{Fe}^{3+}$ in $\mathrm{Fe}^{3+}-\mathrm{O}-\mathrm{Ti}^{4+}$ linkage, and may facilitate the adsorption of negative molecular (such as NO with unpaired electron). This will lead to the higher $\mathrm{NO}$ adsorption and oxidation ability of $\mathrm{Fe}^{3+}$ species, as confirmed by the comparative $\mathrm{NO}_{x}$-TPD results on $\mathrm{Fe}_{2} \mathrm{O}_{3}$ sample and $\mathrm{FeTiO}_{x}$ - $\mathrm{Ti}\left(\mathrm{SO}_{4}\right)_{2}$ catalyst in our previous study [33], which is beneficial to the promotion of low temperature $\mathrm{NH}_{3}$-SCR activity over $\mathrm{FeTiO}_{x}-\mathrm{Ti}\left(\mathrm{SO}_{4}\right)_{2}$ catalyst.

As for $\mathrm{FeTiO}_{x}-\mathrm{TiCl}_{4}$ catalyst, the first-order derivative peak of XANES appears at $7123.4 \mathrm{eV}$, also indicating the presence of $\mathrm{Fe}^{3+}$. The post-edge XANES feature is similar to that of either $\mathrm{Fe}_{2} \mathrm{TiO}_{5}$ or $\mathrm{Fe}_{2} \mathrm{O}_{3}$ reference samples, but the peak is featureless. Therefore, a mixture of $\mathrm{Fe}_{2} \mathrm{TiO}_{5}, \mathrm{Fe}_{2} \mathrm{O}_{3}$ and iron titanate species may exist in this catalyst. Fig. 2C shows the linear fitting results of Fe-K XANES in 
$\mathrm{FeTiO}_{x}-\mathrm{TiCl}_{4}$ catalyst using $\mathrm{Fe}_{2} \mathrm{TiO}_{5}, \mathrm{Fe}_{2} \mathrm{O}_{3}$ and $\mathrm{FeTiO}_{x}-\mathrm{Ti}\left(\mathrm{SO}_{4}\right)_{2}$ as reference samples, based on which we can conclude that a mixture of $c a$. $28 \% \mathrm{Fe}_{2} \mathrm{TiO}_{5}+23 \% \mathrm{Fe}_{2} \mathrm{O}_{3}+$ $49 \%$ iron titanate species derived from $\mathrm{FeTiO}_{x}-\mathrm{Ti}\left(\mathrm{SO}_{4}\right)_{2}$ existed in this catalyst (Table 1). Only half of the $\mathrm{Fe}^{3+}$ species in this catalyst is in the form of active iron titanate crystallite, and accordingly the low temperature $\mathrm{NH}_{3}$-SCR activity over $\mathrm{FeTiO}_{x}-\mathrm{TiCl}_{4}$ catalyst is much lower than that over $\mathrm{FeTiO}_{x}-\mathrm{Ti}\left(\mathrm{SO}_{4}\right)_{2}$ catalyst but higher than that over $\mathrm{Fe}_{2} \mathrm{O}_{3} / \mathrm{TiO}_{2}$ catalyst [24].

Fig. 3A shows the Ti-K XANES of reference samples and $\mathrm{Fe}_{2} \mathrm{O}_{3} / \mathrm{TiO}_{2}$, $\mathrm{FeTiO}_{x}-\mathrm{TiCl}_{4}, \mathrm{FeTiO}_{x}-\mathrm{Ti}\left(\mathrm{SO}_{4}\right)_{2}$ catalysts. Anatase $\mathrm{TiO}_{2}$ is the main crystal phase in $\mathrm{Fe}_{2} \mathrm{O}_{3} / \mathrm{TiO}_{2}$ catalyst. Ti-K XANES of $\mathrm{FeTiO}_{x}-\mathrm{Ti}\left(\mathrm{SO}_{4}\right)_{2}$ catalyst has the strongest pre-edge peak together with broad peak features in the post-edge region, indicating the presence of distorted $\mathrm{Ti}^{4+}$ local structure probably from octahedral coordination. XANES of $\mathrm{FeTiO}_{x}-\mathrm{TiCl}_{4}$ catalyst can be explained by a mixture of $c a .26 \% \mathrm{Fe}_{2} \mathrm{TiO}_{5}+$ $26 \%$ rutile $\mathrm{TiO}_{2}+48 \%$ iron titanate crystallite, as shown by the linear fitting results in Fig. $3 \mathrm{C}$ and Table 1. It is noteworthy that the rutile $\mathrm{TiO}_{2}$ is formed in the $\mathrm{FeTiO}_{x}-\mathrm{TiCl}_{4}$ catalyst instead of anatase $\mathrm{TiO}_{2}$. Another interesting feature is the edge position of Ti-K edge. Fig. 3B shows the first-order derivatives of Ti-K XANES spectra. The absorption energy of $\mathrm{Ti}-\mathrm{K}$ edge in $\mathrm{Fe}_{2} \mathrm{TiO}_{5}$ reference sample with the $\mathrm{Fe}^{3+}-\mathrm{O}-\mathrm{Ti}^{4+}$ linkage where both ions are located nearby is lower than that of anatase $\mathrm{TiO}_{2}$. This can be interpreted simply by the reverse electronic inductive effect by the surrounding $\mathrm{Fe}^{3+}$ species, similarly to the $\mathrm{Fe}-\mathrm{K}$ edge case. $\mathrm{FeTiO}_{x}-\mathrm{Ti}\left(\mathrm{SO}_{4}\right)_{2}$ catalyst has the lowest absorption edge energy, indicating again the presence of most abundant $\mathrm{Fe}^{3+}-\mathrm{O}-\mathrm{Ti}^{4+}$ 
linkage. This phenomenon may universally exist in other Fe-Ti containing catalysts, such as $\mathrm{Fe}^{3+}$-exchanged $\mathrm{TiO}_{2}$-pillared clay catalyst developed by Long and Yang [34] and $\mathrm{Fe}_{2} \mathrm{O}_{3} / \mathrm{TiO}_{2}$ catalyst developed by Kato et al. [35], in which the $\mathrm{Fe}^{3+}-\mathrm{O}-\mathrm{Ti}^{4+}$ structure might also form and play important roles in the $\mathrm{NH}_{3}-\mathrm{SCR}$ reaction.

\subsection{EXAFS}

Fig. 4 depicts the Fourier transform of filtered $k^{3}$-weighted EXAFS oscillations of Fe-K and Ti-K edges into $\mathrm{R}$ space, and all corresponding $k^{3} \cdot \chi(k)$ are shown in Fig. 5. $\mathrm{Fe}_{2} \mathrm{O}_{3} / \mathrm{TiO}_{2}$ catalyst has similar coordination peaks of $\mathrm{Fe}-\mathrm{K}$ and Ti-K edges as those of hematite $\mathrm{Fe}_{2} \mathrm{O}_{3}$ and anatase $\mathrm{TiO}_{2}$, respectively, which is in well accordance with the curve fitting results in Table 2 when using hematite $\mathrm{Fe}_{2} \mathrm{O}_{3}$ and anatase $\mathrm{TiO}_{2}$ as model crystals. As suggested by XANES results, $\mathrm{FeTiO}_{x}-\mathrm{TiCl}_{4}$ catalyst shows peaks in the second coordination shells similar to those of $\mathrm{Fe}_{2} \mathrm{TiO}_{5}, \mathrm{Fe}_{2} \mathrm{O}_{3}$ and rutile $\mathrm{TiO}_{2}$. However, these peaks are much smaller due to the coexistence of iron titanate crystallite. For $\mathrm{FeTiO}_{x}$ - $\mathrm{Ti}\left(\mathrm{SO}_{4}\right)_{2}$ catalyst, the intensity of the second coordination peaks of both $\mathrm{Fe}$ and $\mathrm{Ti}$ is rather low, implying a crystallite state of this sample again. It is noteworthy that only one single peak appears for the second coordination shells of both $\mathrm{Fe}$ and $\mathrm{Ti}$ species in $\mathrm{FeTiO}_{x}-\mathrm{Ti}\left(\mathrm{SO}_{4}\right)_{2}$ catalyst, which is totally different from those of reference samples and the other two catalysts.

The single peak in the second coordination shells of $\mathrm{FeTiO}_{x}-\mathrm{Ti}\left(\mathrm{SO}_{4}\right)_{2}$ catalyst can be assigned to $\mathrm{Fe}^{3+}-\mathrm{O}-\mathrm{Ti}^{4+}$ linkage suggested by the XANES results. The curve fitting results in Table 2 indicate the $\mathrm{Fe}^{3+}-\mathrm{O}-\mathrm{Ti}^{4+}$ distance as $3.09 \pm 0.04 \AA$, which agrees well with the edge shared Fe-O-Ti and Ti-O-Fe structures. Compared to the edge 
shared Fe-O-Ti structure in well crystallized $\mathrm{Fe}_{2} \mathrm{TiO}_{5}$ reference sample, the bond distances of $\mathrm{Fe}-\mathrm{O}-\mathrm{Ti}$ and $\mathrm{Ti}-\mathrm{O}-\mathrm{Fe}$ in this catalyst is $0.09 \AA$ shorter. This is also probably related with the nano effect of $\mathrm{FeTiO}_{x}-\mathrm{Ti}\left(\mathrm{SO}_{4}\right)_{2}$ catalyst in poor crystallinity, of which the catalyst surface possesses a large proportion of unsaturated coordination atoms with shorter average bond distances. The stronger interaction between $\mathrm{Fe}^{3+}$ and $\mathrm{Ti}^{4+}$ species in this catalyst induces the shift of $\mathrm{Fe}-\mathrm{K}$ absorption edge to higher energy

than that of $\mathrm{Fe}_{2} \mathrm{TiO}_{5}$. $\mathrm{Fe}^{3+}$ species must be more positively charged on the catalyst surface and is probably responsible for its highest $\mathrm{NH}_{3}$-SCR activity. After curve fitting, the coordination numbers of Fe-O-Ti and Ti-O-Fe bonds are 2.6 and 2.0, indicating again the small particle size or crystallite phase of iron titanate species in this catalyst.

\subsection{DFT calculation}

In order to further confirm the electronic inductive effect between $\mathrm{Fe}^{3+}$ and $\mathrm{Ti}^{4+}$ species in Fe-Ti containing catalyst, the DFT calculation is applied in this study based on periodical model structures. The Hirshfeld charge of $\mathrm{Fe}$ in stoichiometric $\mathrm{Fe}_{2} \mathrm{O}_{3}$ and $\mathrm{Fe}_{2} \mathrm{TiO}_{5}$ is calculated to be 0.29 and 0.31 , while the value of $\mathrm{Ti}$ in $\mathrm{TiO}_{2}$ and $\mathrm{Fe}_{2} \mathrm{TiO}_{5}$ is calculated to be 0.57 and 0.54 . In $\mathrm{Fe}_{2} \mathrm{TiO}_{5}$, the charge of $\mathrm{Fe}$ and $\mathrm{Ti}$ increases and decreases ca. 7 and 5\% comparing with that in pristine $\mathrm{Fe}_{2} \mathrm{O}_{3}$ and pristine $\mathrm{TiO}_{2}$, respectively. This trend can be clearly seen in the electron density difference map, as shown in Fig. 6. The electron transfers from Fe to the coordinated oxygen and further to neighbouring $\mathrm{Ti}$ atoms (Fig. 6B). Therefore, more charge accumulation (depletion) around $\mathrm{Ti}(\mathrm{Fe})$ can be obtained in $\mathrm{Fe}_{2} \mathrm{TiO}_{5}$ than that in $\mathrm{TiO}_{2}$ 
$\left(\mathrm{Fe}_{2} \mathrm{O}_{3}\right)$, which is in well accordance with the XANES and XPS results as we mentioned above. These results also suggest that in mixed oxide catalyst systems, not only in $\mathrm{FeTiO}_{x}$ catalyst, the charge transfer or electron cloud deviation between different metallic atoms may be an important factor influencing their catalytic activity in certain reactions.

In addition, in order to further confirm the size of the crystallite domains of iron titanate species in $\mathrm{FeTiO}_{x}$-Ti( $\left(\mathrm{SO}_{4}\right)_{2}$ catalyst, the Fe-K EXAFS and Ti-K EXAFS are calculated by FEFF8.4 code using iron titanate crystallite with different atom numbers as models. As the results shown in Fig. 7, besides of the Fe-O and Ti-O coordination peaks in the first shell, only Fe-O-Ti and Ti-O-Fe coordination peaks in the second shell are observed when the atom numbers in iron titanate crystallite are set to 15 , which is mainly due to the inclusion of $\mathrm{Fe}^{3+}-\mathrm{O}-\mathrm{Ti}^{4+}$ linkages with edge shared oxygens in the adopted model. These results are consistent with the EXAFS data of $\mathrm{FeTiO}_{x}-\mathrm{Ti}\left(\mathrm{SO}_{4}\right)_{2}$ catalyst, in which only $\mathrm{Fe}-\mathrm{O}-\mathrm{Ti}$ and $\mathrm{Ti}-\mathrm{O}-\mathrm{Fe}$ coordination peaks in the second shell are also observed. However, increasing the atom numbers further to 27 results in the appearance of another two shoulder peaks in the second coordination shells of $\mathrm{Fe}$ and $\mathrm{Ti}$ species, which is mainly due to the inclusion of $\mathrm{Fe}^{3+}-\mathrm{O}-\mathrm{M}$ and $\mathrm{Ti}^{4+}-\mathrm{O}-\mathrm{M}(\mathrm{M}=\mathrm{Fe}$ or $\mathrm{Ti})$ linkages with corner shared oxygens. These results clearly suggest that the crystallite domains of iron titanate species in $\mathrm{FeTiO}_{x}-\mathrm{Ti}\left(\mathrm{SO}_{4}\right)_{2}$ catalyst are mainly composed by $c a .15$ atoms, which is in well agreement with the very small particle size of iron titanate crystallite that is concluded from EXAFS curve fitting results in section 3.3. 


\subsection{Proposed structure of iron titanate catalyst}

Based on XANES and EXAFS results, a structure model of iron titanate catalyst $\mathrm{FeTiO}_{x}-\mathrm{Ti}\left(\mathrm{SO}_{4}\right)_{2}$ derived from $\mathrm{Ti}\left(\mathrm{SO}_{4}\right)_{2}$ precursor is proposed, as shown in Scheme 1. In this model, the edge shared $\mathrm{Fe}-\mathrm{O}-\mathrm{Ti}$ structure can be denoted as $\mathrm{Fe}^{3+}-(\mathrm{O})_{2}-\mathrm{Ti}^{4+}$, where $\mathrm{Fe}^{3+}$ and $\mathrm{Ti}^{4+}$ species are connected with two edge shared oxygen atoms with shorter $\mathrm{Fe}-\mathrm{Ti}$ bond distance than that in well crystallized $\mathrm{Fe}_{2} \mathrm{TiO}_{5}$. This special structure is in crystallite state, i.e. iron titanate with very small particle size. In other words, the active phase in $\mathrm{FeTiO}_{x}-\mathrm{Ti}\left(\mathrm{SO}_{4}\right)_{2}$ catalyst is macroscopically disordered but microscopically ordered. In this active phase, $\mathrm{Fe}^{3+}$ and $\mathrm{Ti}^{4+}$ species is strongly linked through edge shared fashion, and the electron density around the $\mathrm{Fe}^{3+}$ species is effectively reduced by the surrounding $\mathrm{Ti}^{4+}$ ions, which is beneficial to the enhancement of NO adsorption, oxidation ability and thus the low temperature $\mathrm{NH}_{3}-\mathrm{SCR}$ activity. The presence of $\mathrm{Fe}^{3+}-(\mathrm{O})_{2}-\mathrm{Ti}^{4+}$ structure in $\mathrm{FeTiO}_{x}-\mathrm{Ti}\left(\mathrm{SO}_{4}\right)_{2}$ catalyst may also be responsible for its high resistance to $\mathrm{SO}_{2}$ poisoning due to the low decomposition temperature of sulfate species on $\mathrm{Ti}^{4+}$.

\section{Conclusions}

The micro-structure of iron titanate catalyst $\mathrm{FeTiO}_{x}-\mathrm{Ti}\left(\mathrm{SO}_{4}\right)_{2}$ derived from $\mathrm{Ti}\left(\mathrm{SO}_{4}\right)_{2}$ precursor for $\mathrm{NH}_{3}-\mathrm{SCR}$ of $\mathrm{NO}_{x}$ is studied in detail using XANES and EXAFS methods combined with DFT calculation. Different from the crystal structure of $\mathrm{Fe}^{3+}$ species in hematite $\mathrm{Fe}_{2} \mathrm{O}_{3}$ and $\mathrm{Fe}_{2} \mathrm{O}_{3} / \mathrm{TiO}_{2}$ supported type catalyst, a homogeneous $\mathrm{Fe}^{3+}-(\mathrm{O})_{2}-\mathrm{Ti}^{4+}$ structure is obviously formed in $\mathrm{FeTiO}_{x}-\mathrm{Ti}\left(\mathrm{SO}_{4}\right)_{2}$ catalyst, in which the

$\mathrm{Fe}^{3+}$ and $\mathrm{Ti}^{4+}$ species is strongly linked through an edge shared fashion. As confirmed 
by DFT calculation, the electronic inductive effect is present between $\mathrm{Fe}^{3+}$ and $\mathrm{Ti}^{4+}$ species, which effectively reduces the electron density around the $\mathrm{Fe}^{3+}$, thus leading to the enhancement of NO adsorption, oxidation ability and finally the low temperature $\mathrm{NH}_{3}$-SCR activity. In the future study, we can stabilize this structure onto some catalyst supports with large surface areas for practical use, such as the deNO $\mathrm{N}_{x}$ process for flue gas in coal-fired power plants and diesel engine exhaust for environmental protection.

\section{Acknowledgements}

This work was supported by the National Natural Science Foundation of China (51108446, 50921064), the Ministry of Science and Technology, China (2009AA064802, 2012AA062506), the Specialized Research Foundation for the Gainer of Outstanding Doctoral Thesis and Presidential Scholarship of Chinese Academy of Sciences, the Photon Factory, IMSS-KEK, Japan (Project No. 2009G177), and partially supported by the ITPAJRS program of JSPS, Japan. 


\section{References}

[1] H. Bosch, F. Janssen, Catal. Today 2 (1988) 369.

[2] R.Q. Long, R.T. Yang, J. Am. Chem. Soc. 121 (1999) 5595.

[3] M. Iwasaki, H. Shinjoh, Chem. Commun. 47 (2011) 3966.

[4] M. Iwasaki, K. Yamazaki, K. Banno, H. Shinjoh, J. Catal. 260 (2008) 205.

[5] J. Li, R. Zhu, Y. Cheng, C.K. Lambert, R.T. Yang, Environ. Sci. Technol. 44 (2010) 1799.

[6] J.-H. Park, H.J. Park, J.H. Baik, I.S. Nam, C.-H. Shin, J.-H. Lee, B.K. Cho, S.H. Oh, J. Catal. 240 (2006) 47.

[7] A. Sultana, T. Nanba, M. Haneda, M. Sasaki, H. Hamada, Appl. Catal. B: Environ. $101(2010) 61$.

[8] A. Sultana, T. Nanba, M. Sasaki, M. Haneda, K. Suzuki, H. Hamada, Catal. Today 164 (2011) 495.

[9] G. Carja, G. Delahay, C. Signorile, B. Coq, Chem. Commun. (2004) 1404.

[10]N. Apostolescu, B. Geiger, K. Hizbullah, M.T. Jan, S. Kureti, D. Reichert, F. Schott, W. Weisweiler, Appl. Catal. B: Environ. 62 (2006) 104.

[11]L. Ma, J. Li, R. Ke, L. Fu, J. Phys. Chem. C 115 (2011) 7603.

[12]Z. Si, D. Weng, X. Wu, Y. Jiang, B. Wang, Catal. Sci. Technol. 1 (2011) 453.

[13]M. Kang, E.D. Park, J.M. Kim, J.E. Yie, Catal. Today 111 (2006) 236.

[14]P.G. Smirniotis, D.A. Peña, B.S. Uphade, Angew. Chem. Int. Ed. 40 (2001) 2479.

[15]X. Tang, J. Hao, W. Xu, J. Li, Catal. Commun. 8 (2007) 329.

[16]Z. Wu, B. Jiang, Y. Liu, H. Wang, R. Jin, Environ. Sci. Technol. 41 (2007) 5812. 
[17]A. Sultana, M. Sasaki, H. Hamada, Catal. Today doi:10.1016/j.cattod.2011.09.018.

[18] S. Yang, C. Wang, J. Li, N. Yan, L. Ma, H. Chang, Appl. Catal. B: Environ. 110 (2011) 71 .

[19] Y. Li, H. Cheng, D. Li, Y. Qin, Y. Xie, S. Wang, Chem. Commun. (2008) 1470.

[20]Z. Si, D. Weng, X. Wu, R. Ran, Z. Ma, Catal. Commun. 17 (2012) 146.

[21]J. Li, H. Chang, L. Ma, J. Hao, R.T. Yang, Catal. Today 175 (2011) 147.

[22] G. Cavataio, J. Girard, J.E. Patterson, C. Montreuil, Y. Cheng, C.K. Lambert, SAE Technical Paper 2007-01-1575.

[23]F. Liu, H. He, C. Zhang, Chem. Commun. (2008) 2043.

[24]F. Liu, H. He, C. Zhang, Z. Feng, L. Zheng, Y. Xie, T. Hu, Appl. Catal. B: Environ. 96 (2010) 408.

[25]F. Liu, H. He, J. Phys. Chem. C 114 (2010) 16929.

[26]F. Liu, K. Asakura, H. He, Y. Liu, W. Shan, X. Shi, C. Zhang, Catal. Today 164 (2011) 488 .

[27]J.W. Cook, D.E. Sayers, J. Appl. Phys. 52 (1981) 5024.

[28] A.L. Ankudinov, B. Ravel, J.J. Rehr, S.D. Conradson, Phys. Rev. B 58 (1998) 7565.

[29]B. Delley, J. Chem. Phys. 92 (1990) 508.

[30]B. Delley, J. Chem. Phys. 113 (2000) 7756.

[31] S. Yamazaki, N. Fujinaga, K. Araki, Appl. Catal. A 210 (2001) 97.

[32]F. Liu, K. Asakura, H. He, W. Shan, X. Shi, C. Zhang, Appl. Catal. B 103 (2011) 
369.

[33]F. Liu, H. He, C. Zhang, W. Shan, X. Shi, Catal. Today 175 (2011) 18.

[34] R.Q. Long, R.T. Yang, J. Catal. 186 (1999) 254.

[35]A. Kato, S. Matsuda, F. Nakajima, M. Imanari, Y. Watanabe, J. Phys. Chem. 85 (1981) 1710. 


\section{Figure and scheme captions:}

Fig. 1. Steady-state $\mathrm{NH}_{3}-\mathrm{SCR}$ activity over $\mathrm{Fe}_{2} \mathrm{O}_{3} / \mathrm{TiO}_{2}, \mathrm{FeTiO}_{x}-\mathrm{TiCl}_{4}$ and $\mathrm{FeTiO}_{x}-\mathrm{Ti}\left(\mathrm{SO}_{4}\right)_{2}$ catalysts.

Fig. 2. (A) Fe-K XANES, (B) first-order derivatives of Fe-K XANES in different samples and (C) fitting result of $\mathrm{Fe}-\mathrm{K}$ XANES in $\mathrm{FeTiO}_{x}-\mathrm{TiCl}_{4}$ catalyst using $\mathrm{Fe}_{2} \mathrm{TiO}_{5}$, $\mathrm{Fe}_{2} \mathrm{O}_{3}$ and $\mathrm{FeTiO}_{x}-\mathrm{Ti}\left(\mathrm{SO}_{4}\right)_{2}$ as references.

Fig. 3. (A) Ti-K XANES, (B) first-order derivatives of Ti-K XANES in different samples and (C) fitting result of Ti-K XANES in $\mathrm{FeTiO}_{x}-\mathrm{TiCl}_{4}$ catalyst using $\mathrm{Fe}_{2} \mathrm{TiO}_{5}$, rutile $\mathrm{TiO}_{2}$ and $\mathrm{FeTiO}_{x}-\mathrm{Ti}\left(\mathrm{SO}_{4}\right)_{2}$ as references.

Fig. 4. Fourier transforms of filtered $k^{3} \cdot \chi(k)$ into $\mathrm{R}$ space of (A) Fe-K and (B) Ti-K edges in different samples, where the red dashed lines correspond to the curve fitting results in $\mathrm{R}$ space.

Fig. 5. Filtered $k^{3} \cdot \chi(k)$ of (A) Fe-K edge in the $k$ range of $2.5-15 \AA^{-1}$ and (B) Ti-K edge in the $k$ range of $2.5-13 \AA^{-1}$ in different samples, where the red dotted lines correspond to the curve fitting results in $k$ space.

Fig. 6. Electron density differences of (A) $\mathrm{TiO}_{2}$, (B) $\mathrm{Fe}_{2} \mathrm{TiO}_{5}$, (C) $\mathrm{Fe}_{2} \mathrm{O}_{3}$.

Fig. 7. Fourier transforms of filtered $k^{3} \cdot \chi(k)$ (calculated by FEFF8.4 using different atom numbers in iron titanate crystallite structure) into $\mathrm{R}$ space of (A) Fe-K edge in the $k$ range of $2.5-15 \AA^{-1}$ and (B) Ti-K edge in the $k$ range of $2.5-13 \AA^{-1}$.

Scheme 1. Proposed model of homogeneous edge shared $\mathrm{Fe}^{3+}-(\mathrm{O})_{2}-\mathrm{Ti}^{4+}$ structure in iron titanate catalyst derived from $\mathrm{Ti}\left(\mathrm{SO}_{4}\right)_{2}$ precursor. 
Table 1

Linear fitting results of $\mathrm{Fe}-\mathrm{K}$ and $\mathrm{Ti}-\mathrm{K}$ XANES in $\mathrm{FeTiO}_{x}-\mathrm{TiCl}_{4}$ catalyst

\begin{tabular}{ccccc}
\hline \multirow{2}{*}{ Sample } & \multicolumn{2}{c}{ Fe-K XANES } & \multicolumn{2}{c}{ Ti-K XANES } \\
\cline { 2 - 5 } & Reference & Ratio (\%) & Reference & Ratio (\%) \\
\hline & $\mathrm{Fe}_{2} \mathrm{TiO}_{5}$ & 27.9 & $\mathrm{Fe}_{2} \mathrm{TiO}_{5}$ & 25.9 \\
FeTiO $_{\boldsymbol{x}}-\mathbf{T i C l}_{\mathbf{4}}$ & $\mathrm{Fe}_{2} \mathrm{O}_{3}$ & 23.3 & ${\text { Rutile } \mathrm{TiO}_{2}}$ & 25.8 \\
& $\mathrm{FeTiO}_{x}-\mathrm{Ti}\left(\mathrm{SO}_{4}\right)_{2}$ & 48.9 & $\mathrm{FeTiO}_{x}-\mathrm{Ti}_{\left(\mathrm{SO}_{4}\right)_{2}}$ & 48.3 \\
\hline
\end{tabular}


Table 2

Curve fitting results of $\mathrm{Fe}-\mathrm{K}$ and Ti-K EXAFS in different samples (corrected by the crystallographic data of $\mathrm{Fe}_{2} \mathrm{O}_{3}$, anatase $\mathrm{TiO}_{2}$, rutile $\mathrm{TiO}_{2}$ and $\mathrm{Fe}_{2} \mathrm{TiO}_{5}, \mathrm{M}=\mathrm{Fe}$ or Ti)

\begin{tabular}{|c|c|c|c|c|c|c|}
\hline Sample & Fe-K Reference & Shell & $\mathrm{CN}^{a}$ & $\begin{array}{l}\mathbf{R}^{b} \\
(\AA)\end{array}$ & $\begin{array}{c}\sigma^{2 c} \\
\left(10^{-3} \AA^{2}\right)\end{array}$ & $\begin{array}{c}\text { R factor } \\
(\%)\end{array}$ \\
\hline \multirow{3}{*}{$\mathrm{Fe}_{2} \mathrm{O}_{3}$} & \multirow{3}{*}{$\mathrm{Fe}_{2} \mathrm{O}_{3}$} & $\mathrm{Fe}-\mathrm{O}$ & $6.0 \pm 1.5$ & $1.95 \pm 0.03$ & 10.2 & \multirow{3}{*}{4.2} \\
\hline & & $\mathrm{Fe}^{-\mathrm{Fe}_{1}}$ & $3.0 \pm 0.6$ & $2.97 \pm 0.02$ & 9.0 & \\
\hline & & $\mathrm{Fe}-\mathrm{Fe}_{2}$ & $3.0 \pm 1.0$ & $3.36 \pm 0.02$ & 4.1 & \\
\hline \multirow{3}{*}{$\mathrm{Fe}_{2} \mathrm{TiO}_{5}$} & \multirow{3}{*}{$\mathrm{Fe}_{2} \mathrm{TiO}_{5}$} & $\mathrm{Fe}-\mathrm{O}$ & $3.0 \pm 1.1$ & $1.95 \pm 0.02$ & 7.9 & \multirow{3}{*}{9.0} \\
\hline & & $\mathrm{Fe}-\mathrm{M}_{1}$ & $3.0 \pm 2.3$ & $3.18 \pm 0.04$ & 5.2 & \\
\hline & & $\mathrm{Fe}-\mathrm{M}_{2}$ & $3.0 \pm 2.7$ & $3.67 \pm 0.05$ & 8.6 & \\
\hline \multirow{3}{*}{$\mathrm{Fe}_{2} \mathrm{O}_{3} / \mathrm{TiO}_{2}$} & \multirow{3}{*}{$\mathrm{Fe}_{2} \mathrm{O}_{3}$} & $\mathrm{Fe}-\mathrm{O}$ & $6.6 \pm 1.8$ & $1.96 \pm 0.03$ & 9.8 & \multirow{3}{*}{3.9} \\
\hline & & $\mathrm{Fe}-\mathrm{Fe}_{1}$ & $3.4 \pm 1.1$ & $2.97 \pm 0.02$ & 10.0 & \\
\hline & & $\mathrm{Fe}-\mathrm{Fe}_{2}$ & $3.1 \pm 1.5$ & $3.35 \pm 0.02$ & 4.4 & \\
\hline \multirow{6}{*}{$\mathrm{FeTiO}_{x}-\mathrm{TiCl}_{4}$} & & $\mathrm{Fe}-\mathrm{O}$ & $6.6 \pm 1.8$ & $1.96 \pm 0.02$ & 9.0 & \multirow{6}{*}{9.5} \\
\hline & $\mathrm{Fe}_{2} \mathrm{TiO}_{5}$ & $\mathrm{Fe}-\mathrm{M}_{1}$ & $1.0 \pm 1.0$ & $3.18 \pm 0.04$ & 5.2 & \\
\hline & $* \mathrm{Fe}_{2} \mathrm{O}_{3}$ & $\mathrm{Fe}-\mathrm{M}_{2}$ & $1.0 \pm 2.2$ & $3.67 \pm 0.05$ & 8.6 & \\
\hline & ${ }^{\S}$ Crystallite & $* \mathrm{Fe}-\mathrm{Fe}_{1}$ & $1.0 \pm 1.4$ & $2.97 \pm 0.02$ & 9.0 & \\
\hline & Fe-O-Ti & $* \mathrm{Fe}-\mathrm{Fe}_{2}$ & $1.0 \pm 1.2$ & $3.36 \pm 0.02$ & 4.1 & \\
\hline & & ${ }^{\S} \mathrm{Fe}-\mathrm{Ti}$ & $2.6 \pm 2.5$ & $3.09 \pm 0.04$ & 10.8 & \\
\hline \multirow{2}{*}{$\mathrm{FeTiO}_{x}-\mathrm{Ti}\left(\mathrm{SO}_{4}\right)_{2}$} & Crystallite & $\mathrm{Fe}-\mathrm{O}$ & $7.7 \pm 1.7$ & $1.96 \pm 0.01$ & 9.0 & \multirow{2}{*}{4.5} \\
\hline & $\mathrm{Fe}-\mathrm{O}-\mathrm{Ti}$ & $\mathrm{Fe}-\mathrm{Ti}$ & $2.6 \pm 2.5$ & $3.09 \pm 0.04$ & 10.8 & \\
\hline Sample & Ti-K Reference & Shell & $\mathrm{CN}^{a}$ & $\begin{array}{l}\mathbf{R}^{b} \\
(\AA) \\
\end{array}$ & $\begin{array}{c}\sigma^{2 c} \\
\left(10^{-3} \AA^{2}\right)\end{array}$ & $\begin{array}{c}\text { R factor } \\
(\%)\end{array}$ \\
\hline \multirow{3}{*}{ Anatase $\mathrm{TiO}_{2}$} & \multirow{3}{*}{ Anatase $\mathrm{TiO}_{2}$} & Ti-O & $6.0 \pm 1.0$ & $1.98 \pm 0.01$ & 10.2 & \multirow{3}{*}{1.7} \\
\hline & & $\mathrm{Ti}-\mathrm{Ti}_{1}$ & $3.0 \pm 0.9$ & $3.02 \pm 0.02$ & 5.9 & \\
\hline & & $\mathrm{Ti}-\mathrm{Ti}_{2}$ & $3.0 \pm 1.6$ & $4.03 \pm 0.03$ & 7.7 & \\
\hline \multirow{3}{*}{ Rutile $\mathrm{TiO}_{2}$} & \multirow{3}{*}{ Rutile $\mathrm{TiO}_{2}$} & Ti-O & $6.0 \pm 1.3$ & $1.98 \pm 0.02$ & 9.2 & \multirow{3}{*}{2.9} \\
\hline & & $\mathrm{Ti}-\mathrm{Ti}_{1}$ & $2.0 \pm 1.2$ & $2.96 \pm 0.04$ & 5.0 & \\
\hline & & $\mathrm{Ti}-\mathrm{Ti}_{2}$ & $4.0 \pm 1.4$ & $3.57 \pm 0.02$ & 4.4 & \\
\hline $\mathrm{Fe}_{2} \mathrm{TiO}_{5}$ & $\mathrm{Fe}_{2} \mathrm{TiO}_{5}$ & Ti-O & $6.0 \pm 1.1$ & $1.96 \pm 0.02$ & 11.0 & 3.3 \\
\hline
\end{tabular}




\begin{tabular}{|c|c|c|c|c|c|c|}
\hline & & Ti-M $\mathrm{M}_{1}$ & $3.0 \pm 1.4$ & $3.17 \pm 0.03$ & 6.7 & \\
\hline & & $\mathrm{Ti}^{-} \mathrm{M}_{2}$ & $3.0 \pm 2.8$ & $3.72 \pm 0.05$ & 5.0 & \\
\hline \multirow{3}{*}{$\mathrm{Fe}_{2} \mathrm{O}_{3} / \mathrm{TiO}_{2}$} & \multirow{3}{*}{ Anatase $\mathrm{TiO}_{2}$} & Ti-O & $7.1 \pm 1.8$ & $1.98 \pm 0.01$ & 10.6 & \multirow{3}{*}{1.3} \\
\hline & & $\mathrm{Ti}^{-} \mathrm{Ti}_{1}$ & $3.5 \pm 1.5$ & $3.02 \pm 0.02$ & 6.4 & \\
\hline & & $\mathrm{Ti}-\mathrm{Ti}_{2}$ & $3.5 \pm 2.7$ & $4.04 \pm 0.04$ & 8.5 & \\
\hline \multirow{6}{*}{$\mathrm{FeTiO}_{x}-\mathrm{TiCl}_{4}$} & & Ti-O & $7.3 \pm 1.9$ & $1.97 \pm 0.02$ & 15.6 & \multirow{6}{*}{5.9} \\
\hline & $\mathrm{Fe}_{2} \mathrm{TiO}_{5}$ & Ti-M $M_{1}$ & $0.9 \pm 0.5$ & $3.17 \pm 0.03$ & 6.7 & \\
\hline & *Rutile $\mathrm{TiO}_{2}$ & Ti-M 2 & $0.9 \pm 2.5$ & $3.72 \pm 0.05$ & 5.0 & \\
\hline & ${ }^{\S}$ Crystallite & $* \mathrm{Ti}^{-} \mathrm{Ti}_{1}$ & $0.5 \pm 0.7$ & $2.96 \pm 0.04$ & 5.0 & \\
\hline & \multirow[t]{2}{*}{ Ti-O-Fe } & $* \mathrm{Ti}-\mathrm{Ti}_{2}$ & $1.0 \pm 0.9$ & $3.57 \pm 0.02$ & 4.4 & \\
\hline & & ${ }^{\S} \mathrm{Ti}-\mathrm{Fe}$ & $3.8 \pm 1.7$ & $3.08 \pm 0.04$ & 14.2 & \\
\hline \multirow{2}{*}{$\mathrm{FeTiO}_{x}-\mathrm{Ti}\left(\mathrm{SO}_{4}\right)_{2}$} & Crystallite & Ti-O & $6.9 \pm 1.7$ & $1.97 \pm 0.02$ & 15.6 & \multirow{2}{*}{6.9} \\
\hline & Ti-O-Fe & $\mathrm{Ti}-\mathrm{Fe}$ & $2.0 \pm 1.7$ & $3.08 \pm 0.04$ & 14.2 & \\
\hline
\end{tabular}

${ }^{a} \mathrm{CN}$ : coordination number. ${ }^{b} \mathrm{R}$ : bond distance. ${ }^{c} \sigma$ : Debye-Waller factor. 
Fig. 1

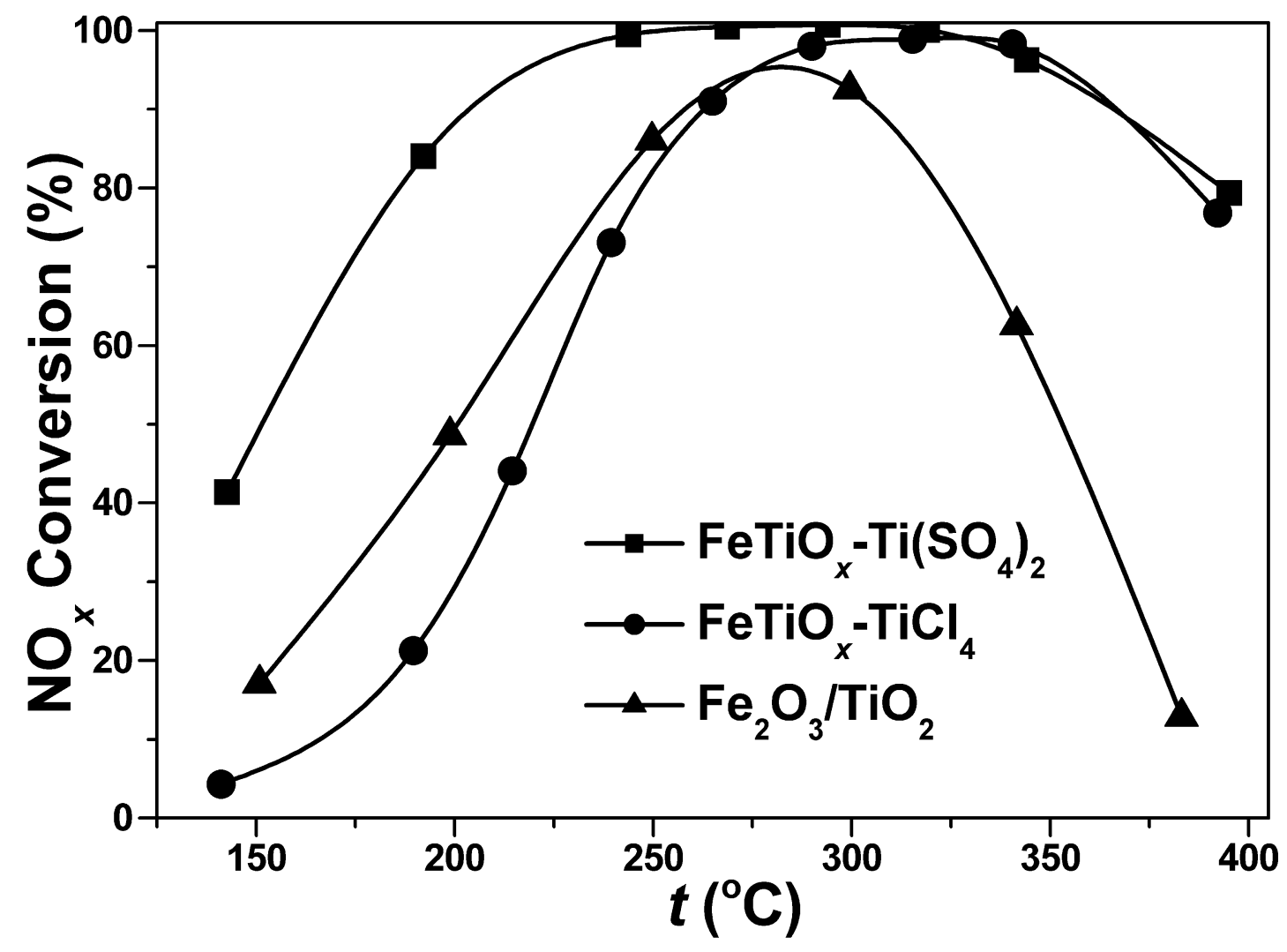


Fig. 2
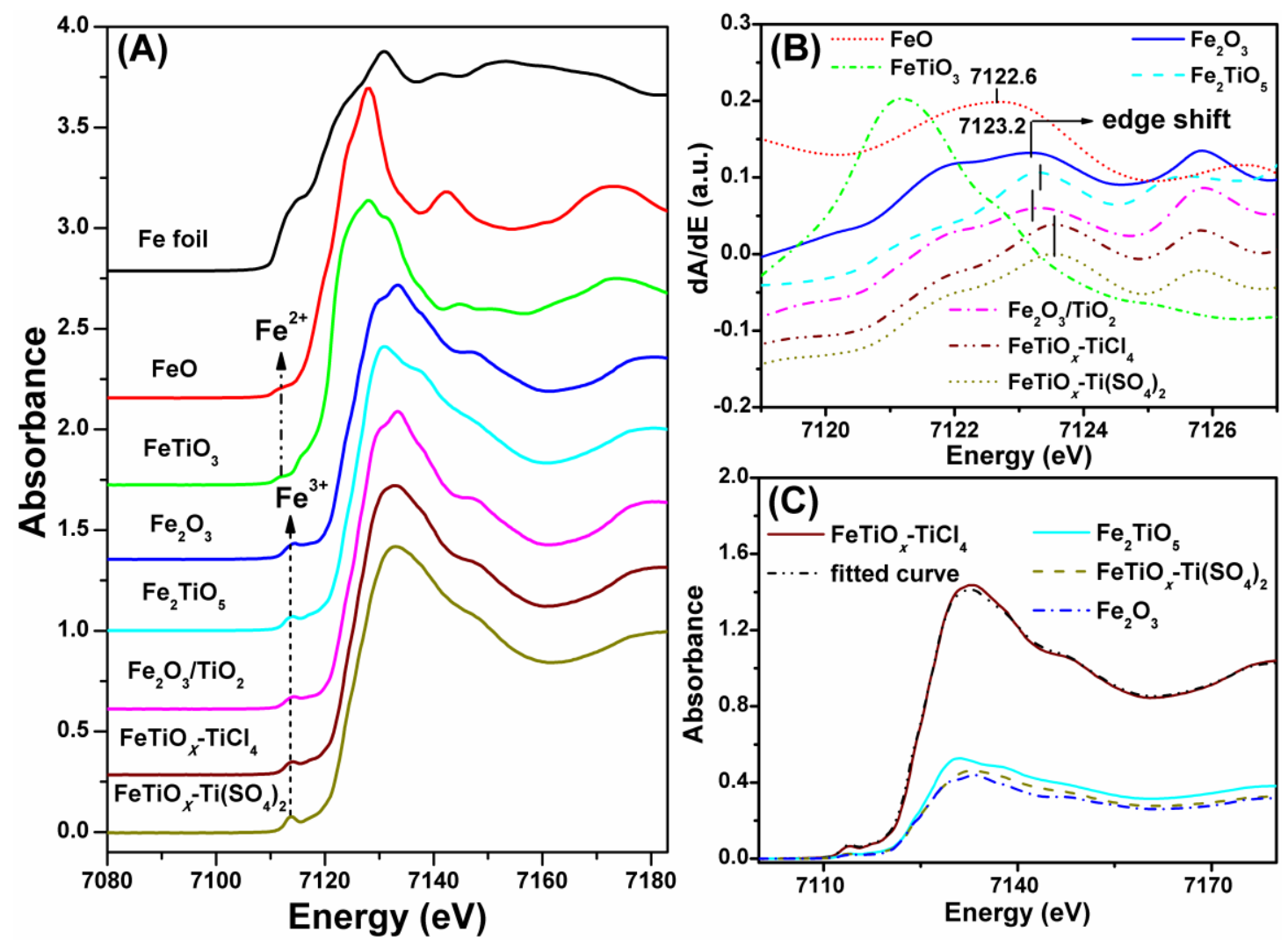
Fig. 3
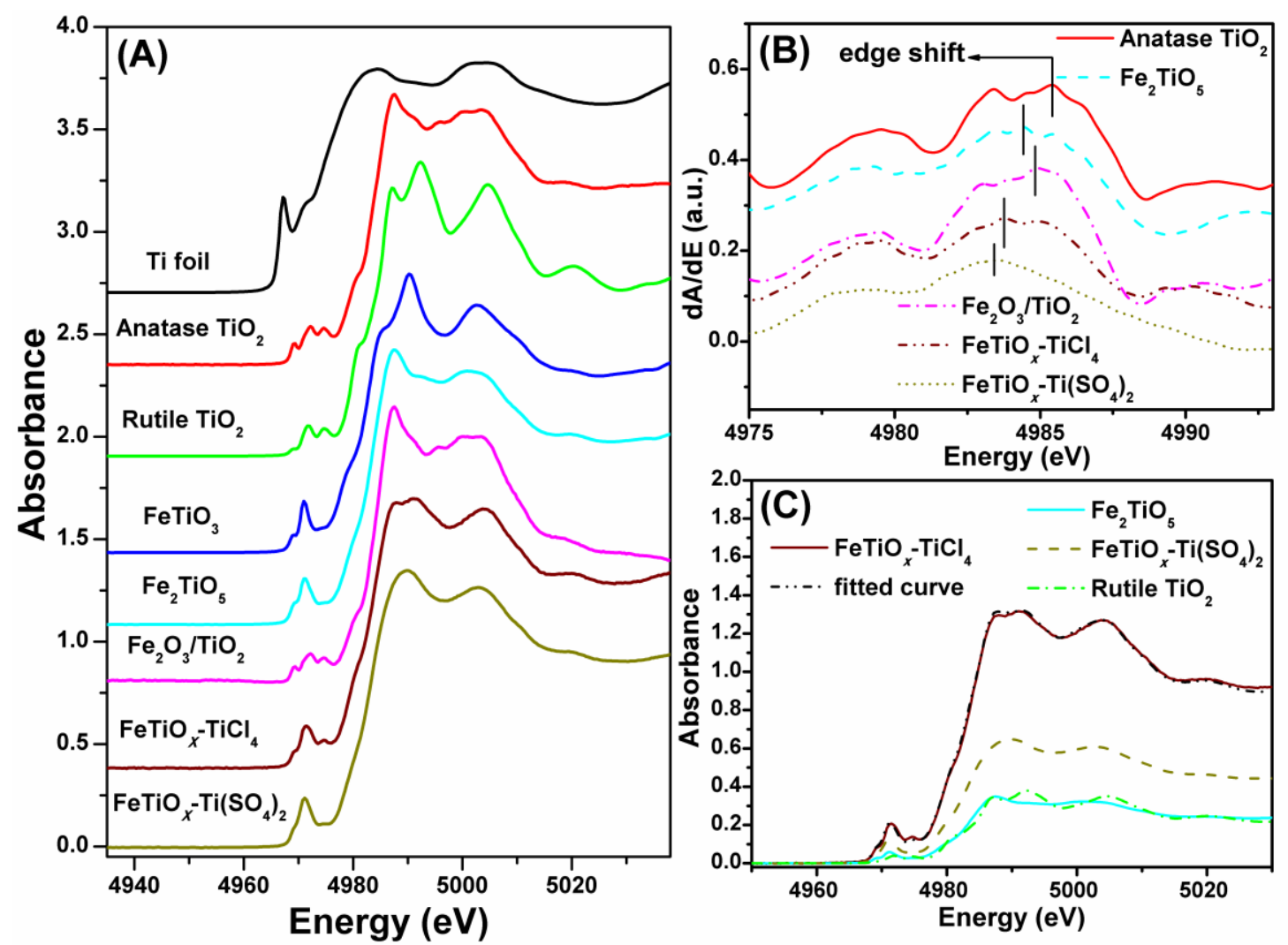
Fig. 4
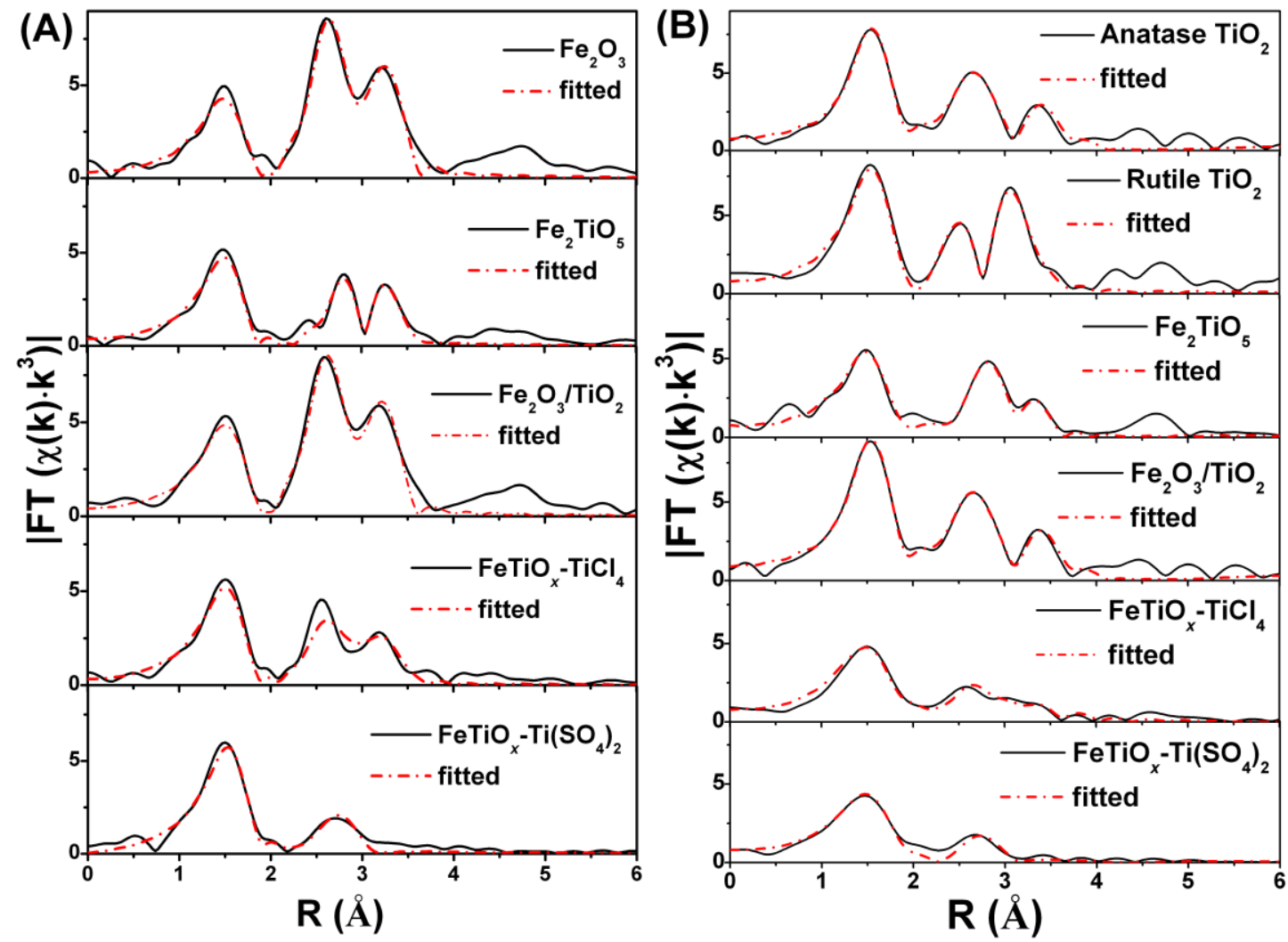
Fig. 5
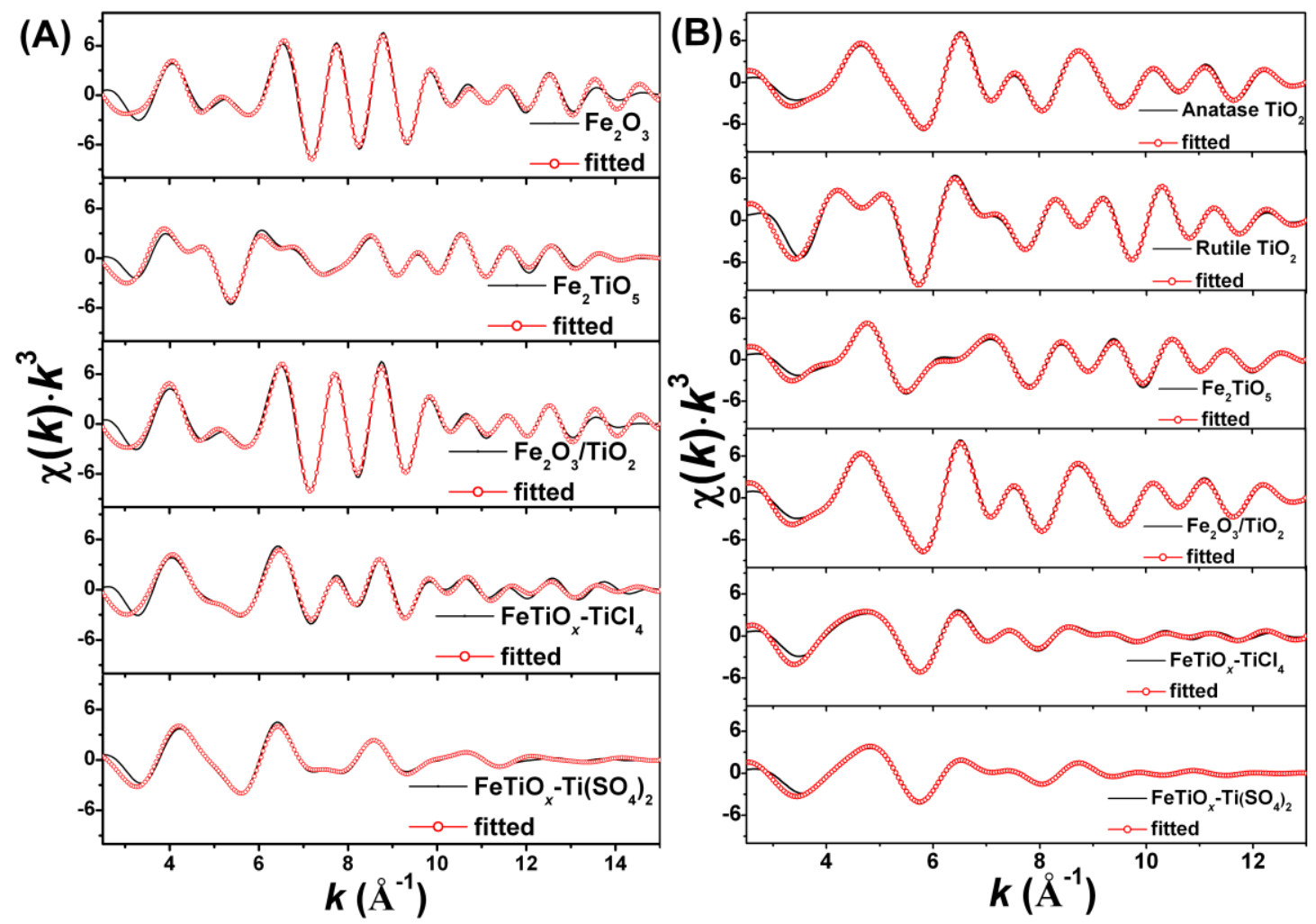
Fig. 6

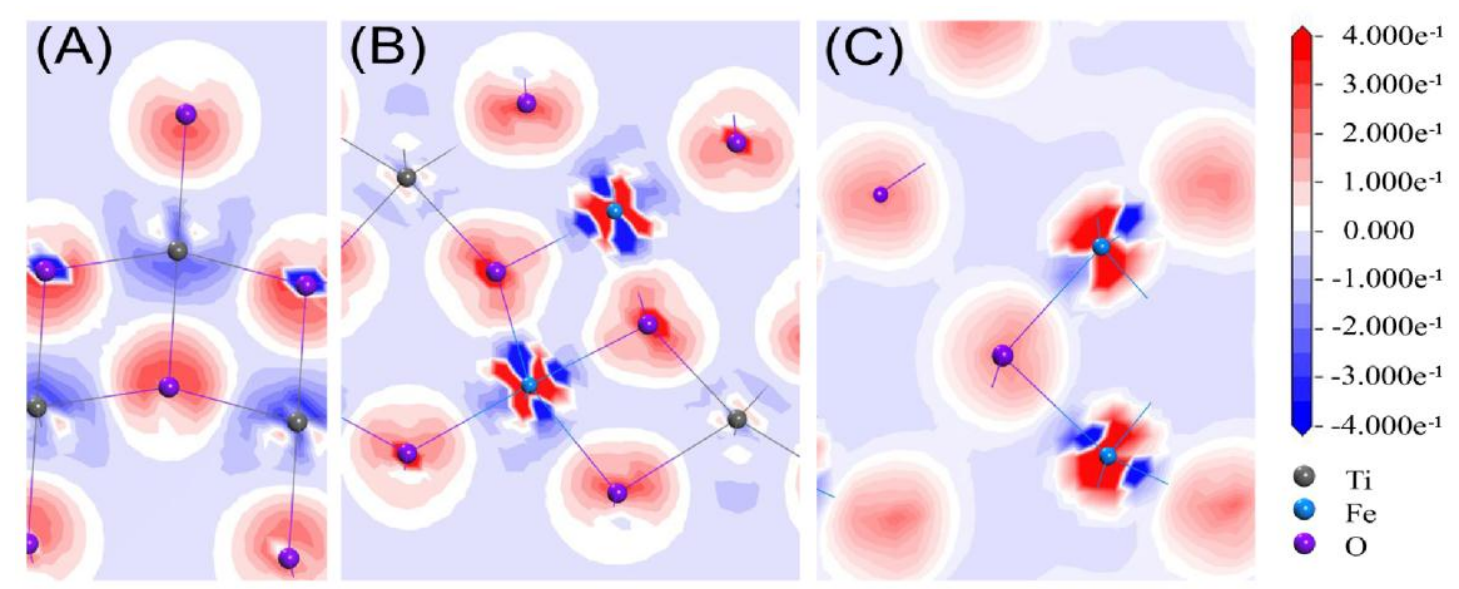


Fig. 7
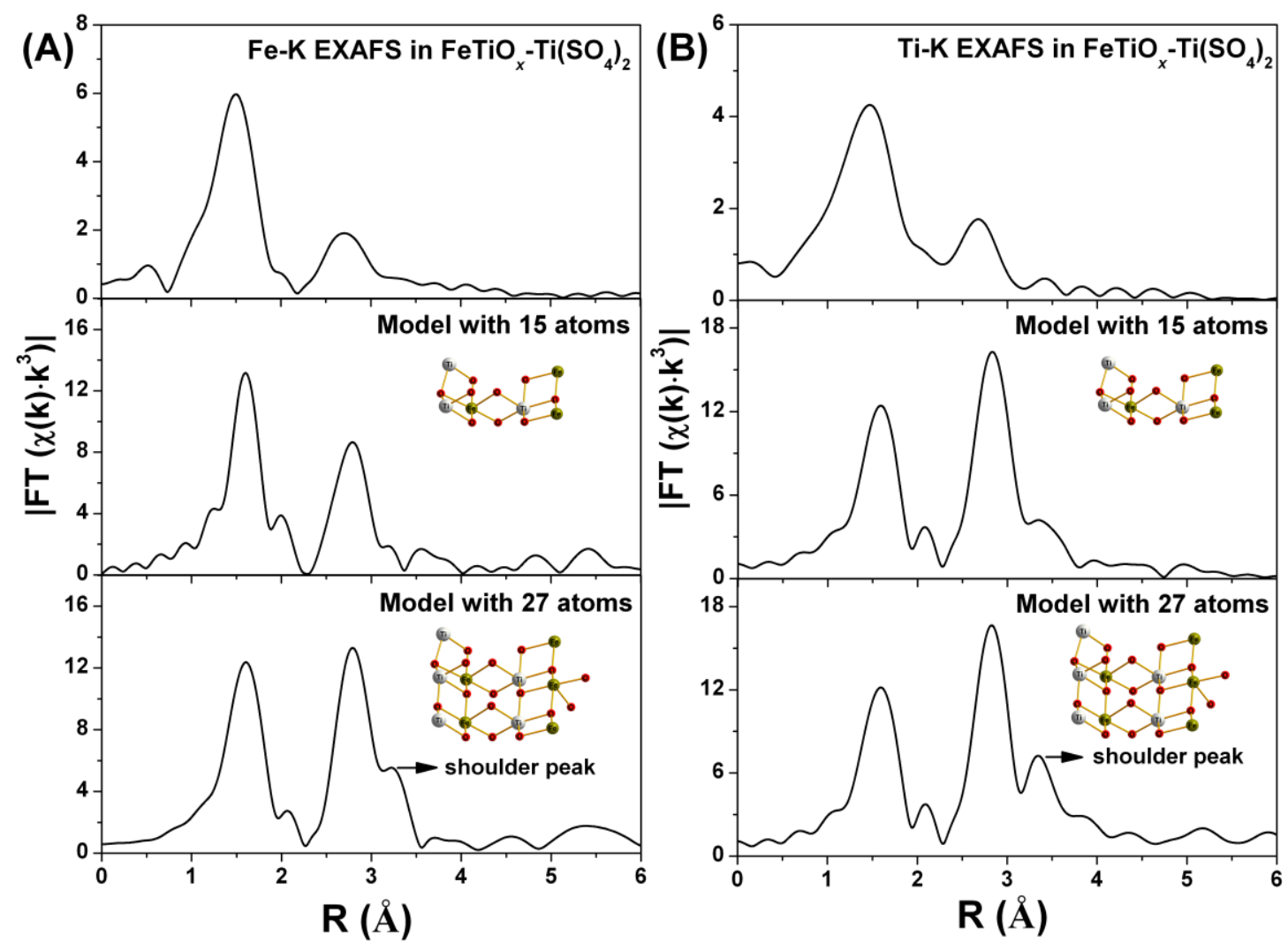
Scheme 1

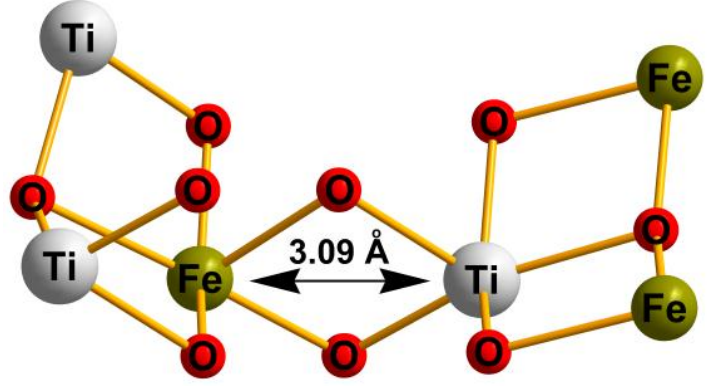

